\title{
The Selection of Best Employee by using Analytical Hierarchy Process Method in Go Wet Water Park
}

\author{
Supriyanti \\ STMIK Nusa Mandiri \\ Jl. Kramat Raya No. 18 \\ Jakarta Pusat 10450 \\ supriyantiupil03@gmail.com
}

\author{
Henny Destiana \\ UBSI Karawang \\ JL. Ahmad Yani No.98 \\ Karawang \\ henny.hnd@bsi.ac.id
}

\begin{abstract}
In a company, human resource is something that must really be considered, the company must have good quality of human resources and be able to work well so that the company's sustainability can be maintained. To maintain the quality and existence of its employees, the company needs to give appreciation to its employees so that employees are motivated to work better. Employees are not motivated to work better because there is no model employee selection yet. Selecting and determining model employees requires a method or decision support system to support the selection of model employees. There are many methods that can be used to select model employees, one of which is the Analytical Hierarchy Process method. To support the selection of model employees, software that can make it easier to determine model employees is needed. The software used is Expert Choice 2000 software. The results obtained from research on the selection of model employees using the Analytical Hierarchy Process method in Go Wet Water Park are employees named Nugraha successfully selected as a model employee in the company with an overall inconsistency of 0.1 .
\end{abstract}

Keywords: Exemplary employee, Analytical Hierarchy Process, Expert 2000 Choice

\section{INTRODUCTION}

In a human resource company, it is something that must really be considered, the company must have quality human resources and be able to work well so that the company's sustainability can be maintained. Employees are important assets for a company, because without employees the company will not be able to run as it should.

To maintain the quality and existence of its employees the company needs to give appreciation to its employees so that employees are motivated to work better. Because so far the company has not made a model of employee selection, so employees are less motivated to work better. In assessing employees, it is certain that a company has specific criteria to determine qualified employees so that employees can be role models and motivate other employees to work well. The criteria used in selecting exemplary employees in each company are certainly different depending on the needs of the company.

To select or determine model employees requires a method or decision support system to support the selection of model employees. There are many methods that can be used to choose model employees, one of which is the Analytical Hierarchy Process method. Go Wet Water Park is part of PT. Putra Tirta Wisata engaged in entertainment or water tourism. Go Wet Water Park was officially opened on May 24, 2015 which is located in Grand Wisata Bekasi. In determining or selecting the best Employee in Go Wet Water Park, it is needed to choose the suitable method.

\section{LITERATURE REVIEW}

Analytical Hierarchy Process is a decision support model developed by Thomas L. Saaty. The decision support system model will describe a multi-factor or complex multi-criteria problem into a hierarchy. A 
hierarchy is defined as a representation of a complex problem in an objective structure, followed by levels of factors, criteria, and so on down to the final level.(Safitri et al. ,2017, p. 18)

In the process of selecting outstanding employees there are several ability categories used by PT XYZ to get the best employees. One of the criteria in question is the ability of hard-skills and soft-skills. However, with this category, it becomes difficult for company leaders to get the best decisions, especially in the relationship between categories, namely collaboration, hard-skills and soft-skills. Therefore we need a method to be able to rank outstanding employees so as to facilitate leaders in the election. Analytic Hierarchy Process (AHP) is a method that can solve decisionmaking problems based on many categories. The ability of hard-skills and soft-skills can be collaborated using AHP so that the linkages between categories make the process of selecting outstanding employees easier. (Suryadi \& Harahap, 2017, p. 1)

There are several that become references, among them:

Performance appraisal of PT. Anugrah Protecindo aims to motivate individual employees and as a determinant in providing employee rewards, but so far it has not been optimal because there is a tendency to focus on performance appraisal which makes the assessment not objective and there is no weighting on the evaluation criteria so it is unknown which criteria most influence employee performance. The purpose of this study is to get the weight of employee performance criteria based on competency using the Analytical Hierarchy Process method. The employee reward system is determined using the profit sharing method based on the percentage increase in performance appraisal achieved by each employee. (Amalia \& Utami 2018, p. 181)

In a company, employees are one of the components in determining the success of a company. A quality workforce will facilitate the company in managing its activities so that the objectives set can be achieved. To get a quality workforce (Human Resources / HR) is not easy for a company. Taking a decision with many criteria requires a special way of handling, especially if the decision making criteria are interrelated. With the increasing number of employees working, then the diversity of employees is also increasingly complex so it is very difficult to choose employees who excel according to the institution and the difficulty of determining priorities. On basically this research can use methods other than AHP, but in this study the authors use the AHP method as an analysis tool because AHP is a single member model that is easy to understand for a variety of unstructured problems, in addition AHP also provides a scale in measuring things that are not realized for get priority (Suroso ,2017, p. 45)

The selection of exemplary employees is already a necessity for several existing agencies or companies. With the selection of exemplary employees, the existing employees will further improve their performance and will provide motivation for other employees. Selected model employees will be given a reward or appreciation for the dedication and performance of employees who have good quality work and who have met the criteria as model employees. For this reason, a decision support system is needed to help find the best alternative in the selection of these employees. The method used in this exemplary employee selection decision support system is the Analytic Hierarchy Process (AHP), (Desyanti ,2016, p. 43):

\section{PROPOSED METHOD}

This stage is a research sequence design from beginning to end in conducting research

\section{Problems}

In this study there are problems namely how to determine the model employees in Go Wet Water Park using the Analytical Hierarchy Process method

2. Approach

The second stage is identifying several problems in selecting the best employee with the right method

3. Development

Software used to support this research is software

Expert Choice 2000

4. Implementation

The object of research in the selection of exemplary employees uses Analytical The Hierarchy Process is Go Wet Water Park.

5. Measurement

Analyze data related to the selection of exemplary employees and measure the criteria related to the selection of exemplary employees using the Analytical Hierarchy Process (AHP) method

6. Result

Analyze data related to the selection of exemplary employees and measure the criteria related to the selection of exemplary employees using the Analytical Hierarchy Process (AHP) method

\section{RESULTS AND DISCUSSION}


A. The following is a hierarchical structure for model employee selection

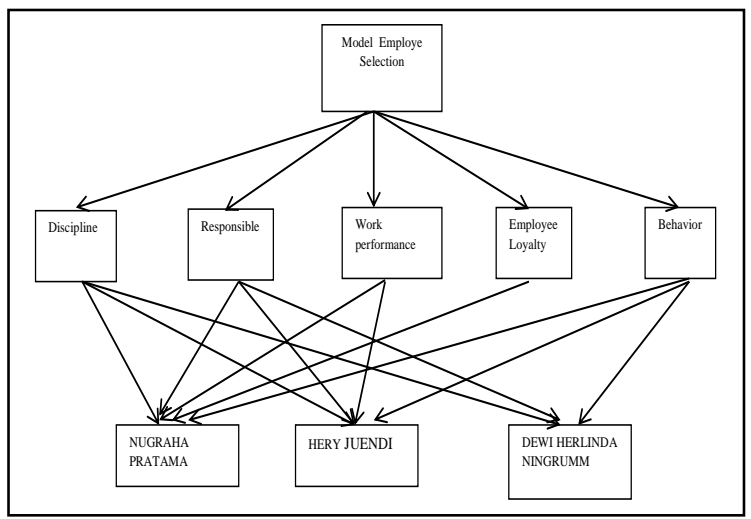

Figure IV.1.

Hierarchical Structure Election of Exemplary Employees

\section{B. Criteria Weighting}

In weighting the criteria of the respondents, there will be inconsistency values that exceed 0.1 . It will not be a problem, because the data has not been obtained fully. The following are the results of weighting criteria based on a questionnaire from 5 respondents:

1. Weighting of first respondent criteria

Table 1.

First Respondent Criteria Weighting

\begin{tabular}{|c|c|c|c|c|c|}
\hline criteria & Discipline & $\begin{array}{c}\text { Respons } \\
\text { ible }\end{array}$ & $\begin{array}{c}\text { Work } \\
\text { performa } \\
\text { nce }\end{array}$ & $\begin{array}{c}\text { Employee } \\
\text { Loyalty }\end{array}$ & $\begin{array}{l}\text { Behavi } \\
\text { or }\end{array}$ \\
\hline Discipline & 1.00 & 1.00 & 3.00 & 1.00 & 5.00 \\
\hline $\begin{array}{c}\text { Responsibl } \\
\mathrm{e}\end{array}$ & 1.00 & 1.00 & 2.00 & 0.50 & 1.00 \\
\hline $\begin{array}{c}\text { Work } \\
\text { performanc } \\
\mathrm{e}\end{array}$ & 0.33 & 0.50 & 1.00 & 1.00 & 1.00 \\
\hline $\begin{array}{c}\text { Employee } \\
\text { Loyalty }\end{array}$ & 1.00 & 2.00 & 1.00 & 1.00 & 4.00 \\
\hline Behavior & 0.20 & 1.00 & 1.00 & 0.25 & 1.00 \\
\hline Amount & 3.53 & 5.50 & 8.00 & 3.75 & 12.00 \\
\hline
\end{tabular}

Value of 0.33 in the discipline work column row is the inverse value of the discipline column work row row. This value is obtained by means of a value of 1.00 in the disciplinary row of the disciplinary column divided by 3.00 in the disciplinary row of the work performance column.
Table 2.

Priority Weighting of First Respondent Criteria

\begin{tabular}{|c|c|c|c|c|c|c|c}
\hline criteria & Discipline & Responsible & $\begin{array}{c}\text { Work } \\
\text { performance }\end{array}$ & $\begin{array}{c}\text { Employee } \\
\text { Loyalty }\end{array}$ & Behavior & Amount & Prior \\
\hline Discipline & 0.28 & 0.18 & 0.38 & 0.27 & 0.42 & 1.52 & 0.3 \\
\hline Responsible & 0.28 & 0.18 & 0.25 & 0.13 & 0.08 & 0.93 & 0.1 \\
\hline $\begin{array}{c}\text { Work } \\
\text { performance }\end{array}$ & 0.09 & 0.09 & 0.13 & 0.27 & 0.08 & 0.66 & 0.1 \\
\hline $\begin{array}{c}\text { Employee } \\
\text { Loyalty }\end{array}$ & 0.28 & 0.36 & 0.13 & 0.27 & 0.33 & 1.37 & 0.2 \\
\hline $\begin{array}{c}\text { Behavior } \\
\text { Amount }\end{array}$ & $\mathbf{0 . 0 6}$ & 0.18 & 0.13 & 0.07 & 0.08 & 0.51 & 0.1 \\
\hline & 1 & 1 & 1 & 1 & 1 & 5 & 1 \\
\hline
\end{tabular}

Table 2 Shows that the disciplinary criteria are the most important criteria in the selection of model employees proven by the highest priority results of 0.30 . Whereas value 5 in the column and row amount is the result of normalization that there are 5 criteria used in the selection of exemplary employees. The value of 1.52 is the sum of the disciplinary lines.

Table 3

Lamda Maximum First Respondent

\begin{tabular}{|c|c|}
\hline Result & Result/Priority \\
\hline 1.67 & $\mathbf{5 . 5 0}$ \\
\hline 0.99 & $\mathbf{5 . 3 4}$ \\
\hline 0.70 & $\mathbf{5 . 3 3}$ \\
\hline 1.49 & $\mathbf{5 . 4 5}$ \\
\hline 0.55 & $\mathbf{5 . 3 6}$ \\
\hline Average & $\mathbf{5 . 4 0}$ \\
\hline
\end{tabular}

The figure above shows that employee loyalty criteria are the most influential criteria or can be the main reference in the selection of exemplary employees. In the results of this combination we get an inconsistency value of 0.01 where this value can be accepted because this value $\leq 0.1$.

1. Alternative Combined Results

Combined alternatives are the result of a combination of five respondents for each criterion in selecting model employees. From the results of this combination can be seen the best alternative of each criterion in the selection of exemplary employees, as well as the value of the ratio of consistency or the final inconsistency value of weighting all alternatives on each criterion. 


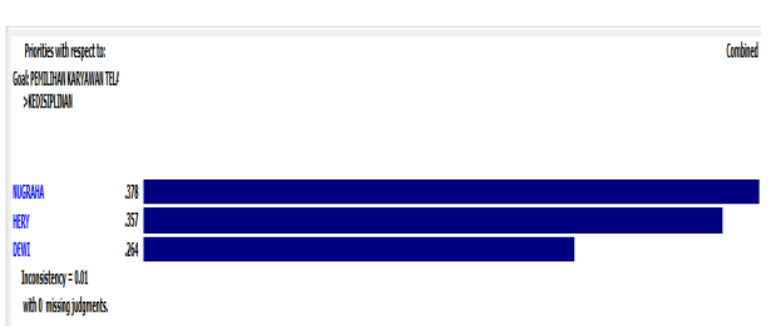

Figure 1

Combined Alternatives to Disciplinary Criteria

The picture above shows that Nugraha gets the highest priority in the discipline criteria. In the results of this combination we get an inconsistency value of 0.01 where this value can be accepted because this value $\leq$ 0.1 .

2. Combined alternative responsibilities criteria

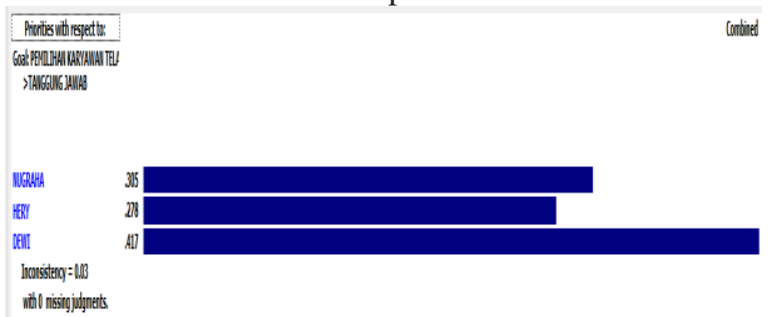

Figure 2 Combined Alternatives to Responsibility Criteria

The picture above shows that Dewi gets the highest priority on the criteria of responsibility. In the results of this combination we get an inconsistency value of 0.03 where this value is acceptable because this value $\leq 0.1$.

3. Combined alternative work performance criteria

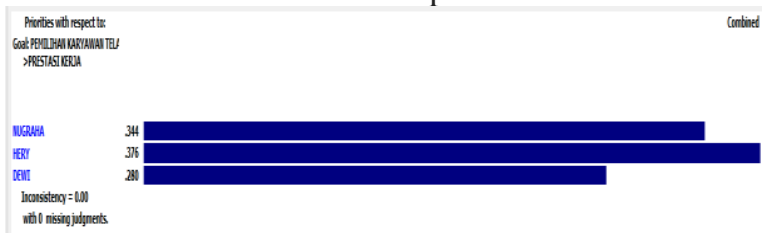

Figure 3 Combined Alternatives to Job Performance Criteria

The picture above shows that Hery received the highest priority on work performance criteria. In the results of this combination we get an inconsistency value of 0.00 where this value can be accepted because this value $\leq$ 0.1 .

\section{Combined alternative employee loyalty criteria}

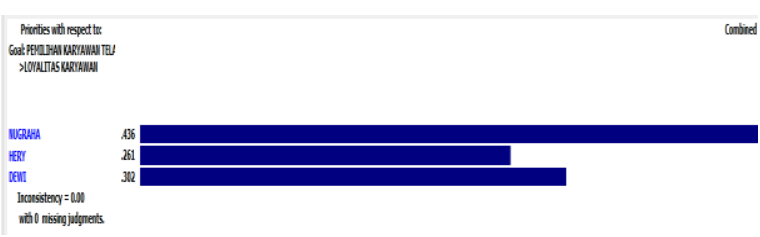

Figure 4 Combined alternative employee loyalty criteria

The picture above shows that Nugraha gets the highest priority on employee loyalty criteria. In the results of this combination we get an inconsistency value of 0.00 where this value can be accepted because this value $\leq$ 0.1 .

5. Combined alternative behavioral criteria

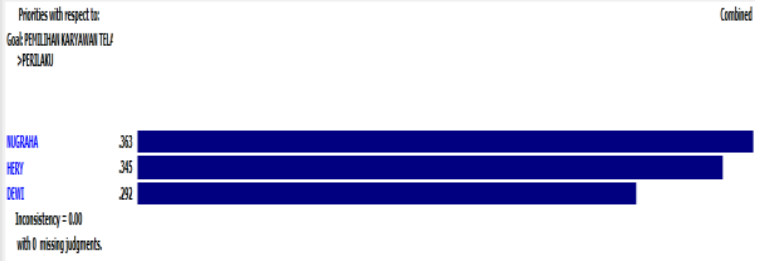

Figure 5 Combined Alternatives to Behavioral Criteria

The picture above shows that Nugraha gets the highest priority on behavioral criteria. In the results of this combination we get an inconsistency value of 0.00 where this value can be accepted because this value $\leq$ 0.1 .

7. Model Employee Election Results

From the results of an alternative combination of the five criteria and from the five respondents the best alternative results have been obtained from the five criteria that have been set by the researcher. These results will show who is a model employee at GO Wet Water Park.

\section{CONCLUSIONS AND SUGGESTIONS}

The conclusions resulting from research on the selection of exemplary employees using the Analytical Hierarchy Process method in Go Wet Water Park are as follows :

1. Nugraha was chosen to be a model employee of

Go Wet Water Park with an overall inconsistency of 0.1. Therefore the first hypothesis H1: there is a model employee at Go Wet Water Park can be accepted. 
2. Employee loyalty criteria are the most influential criteria or can be the main reference in the selection of Go Wet Water Park's exemplary employees with inconsistencies of 0.01 . Thus the second hypothesis $\mathrm{H} 1$ : There is a criterion that most influences the selection of model employees at Go Wet Water Park is acceptable.

3. Analytical Hierarchy Process method is the right method in solving problems regarding the selection of exemplary employees. Thus the third hypothesis H1: Analytical Hierarcy Process Method is an appropriate method in selecting acceptable model employees.

4. Expert Choice 2000 is the right tool to help solving decision-making problems. In this case Expert Choice 2000 helped to complete the selection of model employees at the Go Wet Water Park.

As for the suggestions submitted so that future research can be better. The suggestions are as follows:

1. For future research, the object of research can be expanded again.

2. The research sample used in future research must be more.

3. Distributing questionnaires to respondents to obtain the data needed in research can be reproduced

4. The criteria used can be added again, according to the research theme. more in-depth about the material to be studied and the methods to be used, because it will greatly affect the process and the results that will be obtained.

\section{VI.REFERENCES}

Safitri, Kamalia, Fince Tanus Waruwu dan Mesran. 2017. Sistem Pendukung
Keputusan Pemilihan Karyawan Berprestasi Dengan Menggunakan Metode Analytical Hierarchy Process (Studi Kasus : PT. Capella Dinamik Nusantara Takengon). Media Informatika Budidarma. Vol. 1, No. 1, Maret 2017.

Suryadi, Andri dan Erwin Harahap. 2017. Pemeringkatan Pegawai Berprestasi menggunakan Metode AHP (Analytical Hierarchy Process) di PT. XYZ. Vol. 16, No. 2, November 2017.

Amalia, Multi Rizky dan Dwi Yuni Utami. 2018. Pemberian Reward Berdasarkan Penilaian Kinerja Karyawan Dengan Metode AHP pada PT. Anugrah Protecindo. Jurnal Ilmu Pengetahuan dan Teknologi Komputer. Vol. 3. No. 2 Februari 2018.

Suroso, Amat. 2017. Sistem Pendukung Keputusan Penilaian Karyawan Terbaik PT. Suteckaria Indonesia Dengan Metode Analytical Hierarchy Process. Vol. 01, No. 02, Juni 2017, pp. 45-50.

Desyanti. 2016. Sistem Pendukung Keputusan Pemilihan Karyawan Teladan Menggunakan Metode Analiticy Hierarchy Process (AHP). Jurnal Infotek Polbeng-Seri Informatika. Vol. 1, No. 1, Juni 2016. 